\title{
IMPLEMENTASI ENERGI BIOMASSA DALAM BENTUK PENYEBARAN LUBANG RESAPAN BIOPORI DI FAKULTAS HUKUM UNIVERSITAS KRISNADWIPAYANA
}

\author{
Christine Widyastuti ${ }^{1}$, Isworo Pujotomo ${ }^{2}$, Muchammad Nur Qosim ${ }^{3}$, Rinna Hariyati ${ }^{4}$, Aas \\ Wasri Hasanah $^{5}$, Tony Koerniawana ${ }^{6}$, Oktaria Handayani ${ }^{7}$ \\ 1,2,3,4,5,6,7 Sekolah Tinggi Teknik PLN ; Jakarta \\ Teknik Elektro \\ email : ${ }^{* 1}$ christinewidyastuti@gmail.com
}

\begin{abstract}
Abstrak
Salah satu kawasan yang rawan akan dampak musim hujan yang kemudian menjadi kawasan yang rawan akan banjir tentulah kawasan yang padat penduduk dan tidak memiliki drainese air yang cukup. Dimana lahan yang seharusnya dapat menjadi lahan resapan air justru tertutup oleh bangunan - bangunan. Untuk mengatasi hal ini maka salah satu solusinya adalah membuat lubang - lubang resapan air kembali meskipun di lahan yang sempit.Di dalam lubang lubang yang berdiameter $10 \mathrm{~cm}$ dan kedalaman $80 \mathrm{~cm}-100 \mathrm{~cm}$ tersebut dapat dimasukkan sampah organik berupa daun kering ataupun sampah rumah tangga ( sampah dapur ). Sampah organik ini berfungsi membantu kehidupan cacing tanah dan rayap yang nantinya akan membuat biopori ( pori/kecil) di dalam tanah. Di saluran air, lubang resapan ini bisa dibuat setiap satu meter. Dan dari lubang resapan biopori ini pula dapat diambil hasil panen dalam bentuk pupuk organik ( energi biomassa) yang bernilai ekonomis. Dengan alasan inilah maka sosialisasi ini di laksanakan di lingkungan Fakultas Hukum Universitas Krisnadwipayana.
\end{abstract}

Kata kunci: biopori, sampah organik, energi biomassa

\begin{abstract}
One area prone to the impact of the rainy season which later becomes an area prone to flooding is certainly an area that is densely populated and does not have sufficient water drainage. Where land that could have become water absorption land is actually covered by buildings. To overcome this problem, one of the solutions is to make water infiltration holes back even on narrow land. In holes that are $10 \mathrm{~cm}$ in diameter and $80 \mathrm{~cm}-100 \mathrm{~cm}$ deep, organic waste in the form of dried leaves or household waste can be inserted. (kitchen garbage). This organic waste serves to help the life of earthworms and termites which will later make biopores (pores / small) in the soil. In waterways, this infiltration hole can be made every one meter. And from this biopore infiltration hole, harvest yields can also be taken in the form of organic fertilizer (biomass energy) which has economic value. For this reason, this dissemination was carried out in the Faculty of Law Krisnadwipayana University.
\end{abstract}

Keywords: biopori, organic waste, biomass energy 


\section{PENDAHULUAN}

Dalam kegiatan Pengabdian Pada Masyarakat ( P2M ) kali ini kami mengambil topik tentang Lubang Resapan Biopori, dimana topik ini kami ambil karena mengingat akan datang kembali musim penghujan. Dimana cukup banyak wilayah yang mengalami banjir dan atau genangan air dikarenakan kurang baiknya sistem drainese airnya. Beberapa kendala yang sering dihadapi dari tidak baiknya drainese air dianataranya karena lahan serapan air berkurang karena sudah tertutup oleh bangunan-bangunan dan karena sampahsampah yang seringkali menyumbat aliran air. Untuk lokasi yang kami pilih sebagai spot P2M kali ini adalah di Fakultas Hukum Universitas Krisnadwipayana, mengingat adanya laporan di lokasi ini seringkali terjadi genangan air yang cukup timggi saat musim penghujan datang. Dan lokasi inipun setelah kami tinjau ternyata sistem drainese airnya kurang baik dan tidak adanya lubang resapan biopori ( LRB ) yang secara tidak langsung bermanfaat sebagai lubang-lubang resapan air. Terlebih dengan adanya LRB ini sampah organik yang di sekitar lokasi ini dapat pula dimanfaatkan sebagai pengisi LRB yang tersebar dan dalam waktu 3 bulan dapat dipanen hasilnmya dalam bentuk pupuk organik. sehingga dari hasil panen inipun dapat bernilai ekonomis.

Metode lubang resapan biopori (LRB) sendiri adalah lubang silindris yang dibuat ke dalam tanah dengan diameter $10 \mathrm{~cm}$, kedalaman sekitar $100 \mathrm{~cm}$ atau jangan melebihi kedalaman muka air tanah. Lubang yang baru dibuat serta telah diisi sampah bisa memasukan air sebanyak 1,5 liter hingga 16 liter per menit. Lubang resapan biopori (LRB) adalah lubang-lubang ( pori ) tanah yang yang berfungsi untuk menjebak air yang mengalir di sekitarnya sehingga dapat menjadi sumber cadangan air bagi air bawah tanah, tumbuhan di sekitarnya serta dapat juga membantu pelapukan sampah organik menjadi kompos yang bisa dipakai untuk pupuk tumbuh-tumbuhan. Lubang ( pori ) terbentuk akibat aktivitas organisme di dalamnya, seperti cacing, perakaran tanah, rayap, dan fauna tanah lainnya. Dengan adanya aktivitas fauna tanah pada lubang resapan maka biopori akan terjaga kemampuannya dalam menyerap air dan akan terus terpelihara keberadaannya Selain dapat meresapkan air dengan cepat, juga dapat menjaga ketersediaan cadangan air tanah dikala musim kemarau datang, serta juga dapat meminimalisir sampah organik yang berserakan dan mengolahnya menjadi kompos dengan cara memasukan media sampah-sampah organik, seperti daun, rumput, sampah rumah tangga, dan sampah lainnya ke dalam lubang biopori.

Banyak sekali manfaat yang dapat diperoleh dari biopori, bila kita mau menerapkannya di lingkungan sekitar. Namun, hasil penerapan biopori akan lebih memuaskan jika kita semua mau bergotong-royong untuk menerapkannya secara bersamasama di lingkungan. Semakin banyak yang menerapkan, maka semakin besar manfaat yang kita peroleh. 


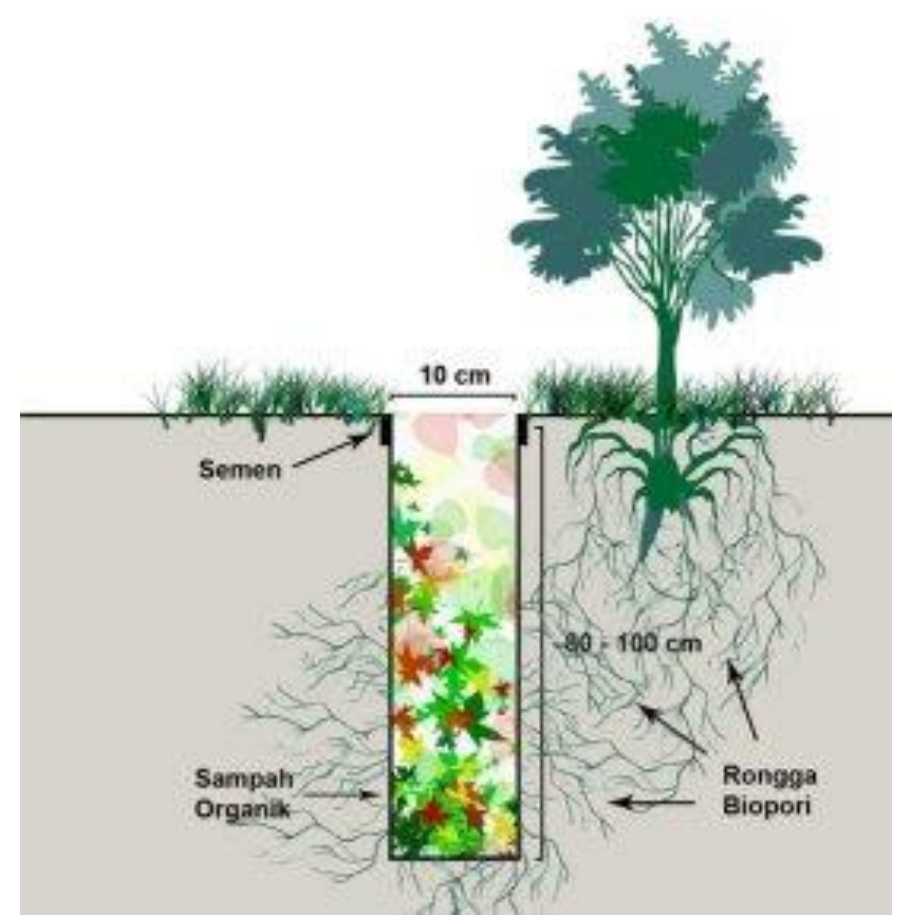

Gambar 1. Lubang Resapan Biopori ( LRB )

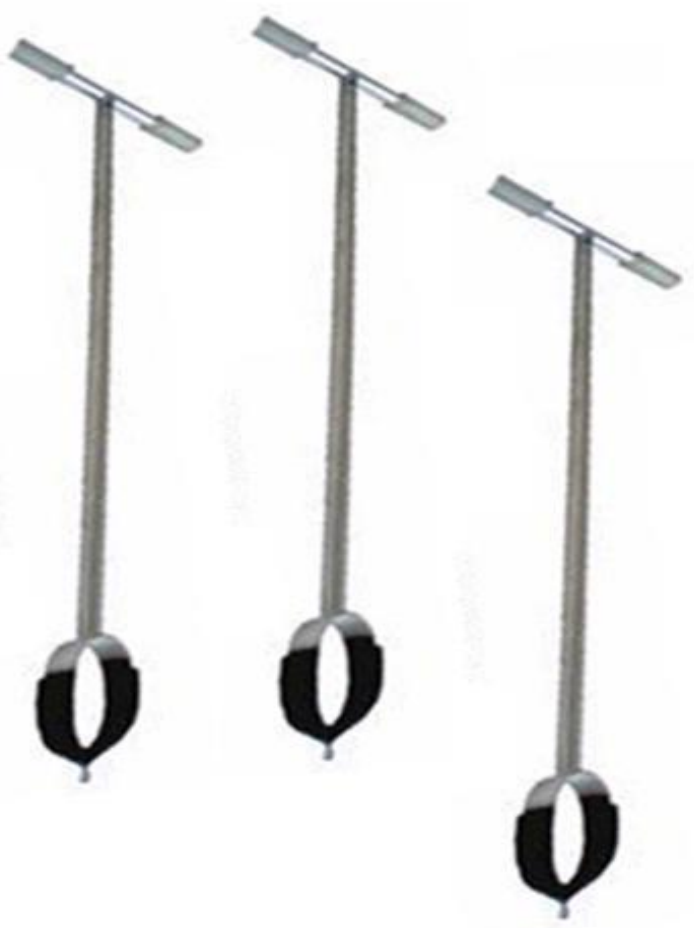

Gambar 2. Alat Bor Biopori 
Sebagai contoh untuk daerah dengan intensitas hujan $50 \mathrm{~mm} / \mathrm{jam}$ (hujan lebat), dengan laju peresapan air perlubang 3 liter/menit (180 liter/jam) pada $100 \mathrm{~m} 2$ bidang kedap perlu dibuat sebanyak $(50$ x 100): $180=28$ lubang. Bila lubang yang dibuat berdiameter $10 \mathrm{~cm}$ kedalaman $100 \mathrm{~cm}$, setiap lubang dapat menampung 7,8 liter sampah organik, berarti tiap lubang dapat diisi sampah organik dapur 2-3 hari. Dengan demikian 28 lubang baru dapat dipenuhi sampah organik yang dihasilkan selama 56- 84 hari, di mana dalam kurun waktu tersebut lubang perlu diisi kembali.

Lubang resapan biopori adalah teknologi tepat guna dan ramah lingkungan untuk mengatasi banjir dengan cara :
a. Meningkatkan daya resapan air
b. Mengubah sampah organic menjadi kompos
c. Memanfaatkan peran aktifitas fauna tanah dan akar tanaman

Adapun beberapa manfaat dan keunggulan LRB adalah sebagai berikut :

a Memaksimalkan air yang meresap ke dalam tanah sehingga menambah air tanah.

b Membuat kompos alami dari sampah organik daripada dibakar.

c Mengurangi genangan air yang menimbulkan penyakit.

d Mengurangi air hujan yang dibuang percuma ke laut.

e Mengurangi resiko banjir di musim hujan.

f Maksimalisasi peran dan aktivitas flora dan fauna tanah.

g Mencegah terjadinya erosi tanah dan bencana tanah longsor.

\section{METODE PELAKSANAAN}

Metode pelaksanaan yang digunakan dalam pelaksanaan P2M ini adalah :

Penyuluhan implementasi energi biomassa dalam bentuk penyebaran lubang resapan biopori dilakukan dalam satu sesi yang diikuti oleh 40 - 50 orang peserta. Kegiatan ini dapat dilaksanakan dalam jangka waktu sekurang-kurangnya 4 (empat) hari kerja. Setiap peserta akan diberikan materi berupa pengetahuan dan praktek pembuatannya. Langkah 1 : Peserta diberikan materi tentang hukum lingkungan.

Langkah 2 : Peserta diberikan materi tentang apakah teknologi lubang resapan biopori ( LRB ).

Langkah 3 : Peserta diberikan teori tentang apakah itu energi biomassa.

Langkah 4 : Setelah peserta diberikan teori-teori tersebut, kemudian peserta akan diberikan contoh cara pembuatan dan penerapan LRB, serta bagaimanakah perawatan dan pemeliharaan dari LRB.

Langkah 5 : Peserta diharapkan dapat melanjutkan dan menyebarluaskan penyebaran LRB. 


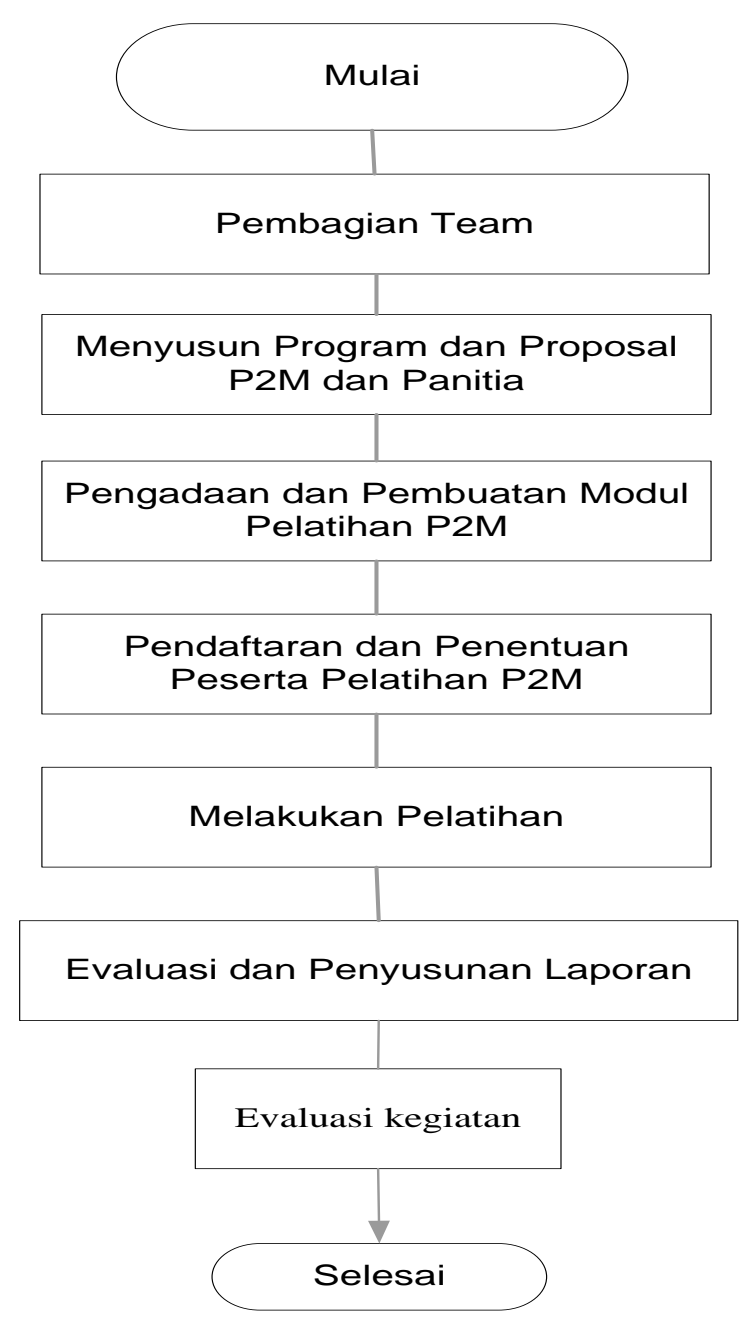

Gambar 3. Diagram Alir P2M

\section{HASIL DAN PEMBAHASAN}

Hasil kegiatan P2M secara garis besarnya dapat dilihat berdasarkan beberapa komponen berikut ini :

a. Keberhasilan target jumlah peserta yang mencapai $100 \%$. Hal ini terlihat dari daftar hadir sebanyak 60 orang, dengan mayoritas yang hadir adalah para dosen dan mahasiswa Fakultas Hukum UNKRIS mulai dari persiapan, penyebaran undangan, pengadaan konsumsi, tempat dan peralatan pendukung lainnya.

b. Ketercapaian tujuan sosialisasi mencapai $90 \%$. Hal ini terlihat dari adanya peningkatan pengetahuan peserta dari yang tidak memahami tentang teknik lubang resapan biopori. 
c. Meningkatnya pemahaman peserta tentang apakah itu lubang resapan biopori, apakah hubungan antara hukum lingkungan dengan lubang resapan biopori, dan apakah manfaat lubang resapan biopori baik dari segi teknik maupun non teknik.

d. Ketercapaian target materi yang disampaikan mencapai $80 \%$. Hal ini terlihat dari bagaimana para peserta membuat lubang resapan biopori dan keberhasilan mitra di dalam menyebarkan LRB dan memanen hasil LRB dalam waktu 3(tiga) bulan dalam bentuk pupuk organik.

e. Secara keseluruhan kegiatan PKM berupa sosialisasi implementasi energi biomassa melalui penyebaran lubang resapanm biopori di lingkungan Fakultas Hukum UNKRIS ini berhasil, dikarenakan semakin bertambahnya penyebaran LRB dan menciptakan drainese air yang baik dan tersebar.

Berikut adalah hasil sosialisasi dan pelatihan teknik lubang resapan biopori :

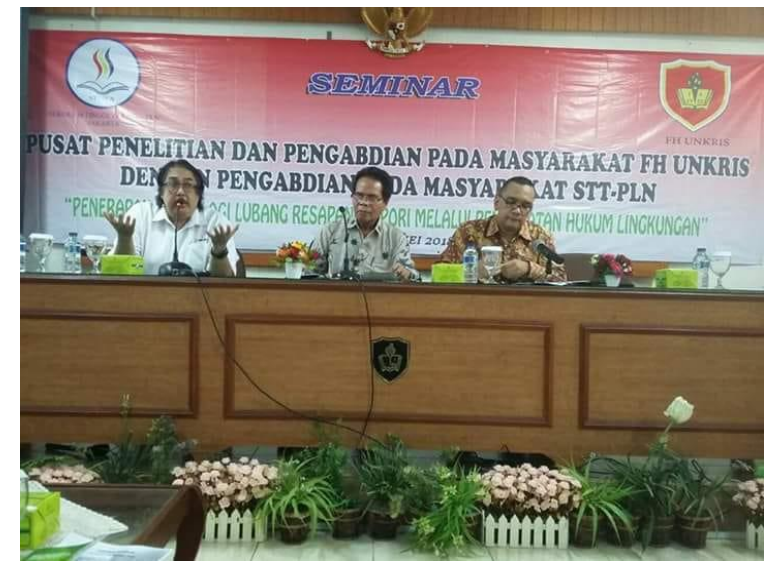

Gambar 4. Sosialisasi Pemaparan Materi Tentang LRB

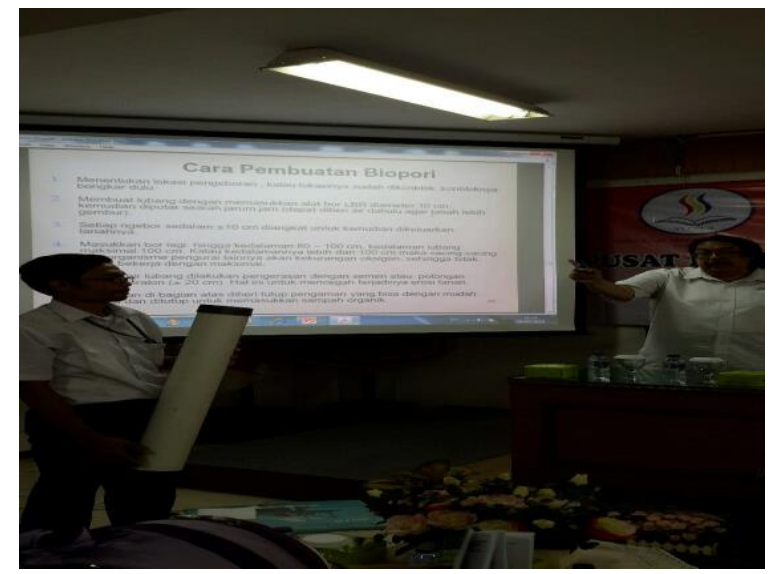

Gambar 5. Contoh Perlengkapan yang digunakan untuk LRB 


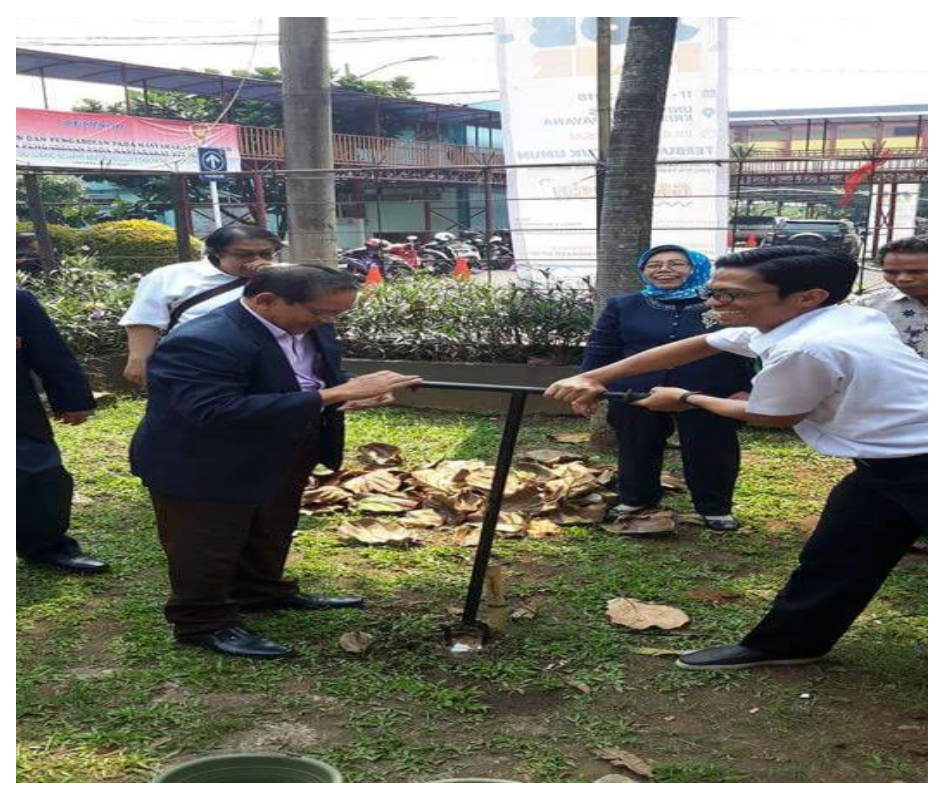

Gambar 6. Praktek Pembuatan LRB

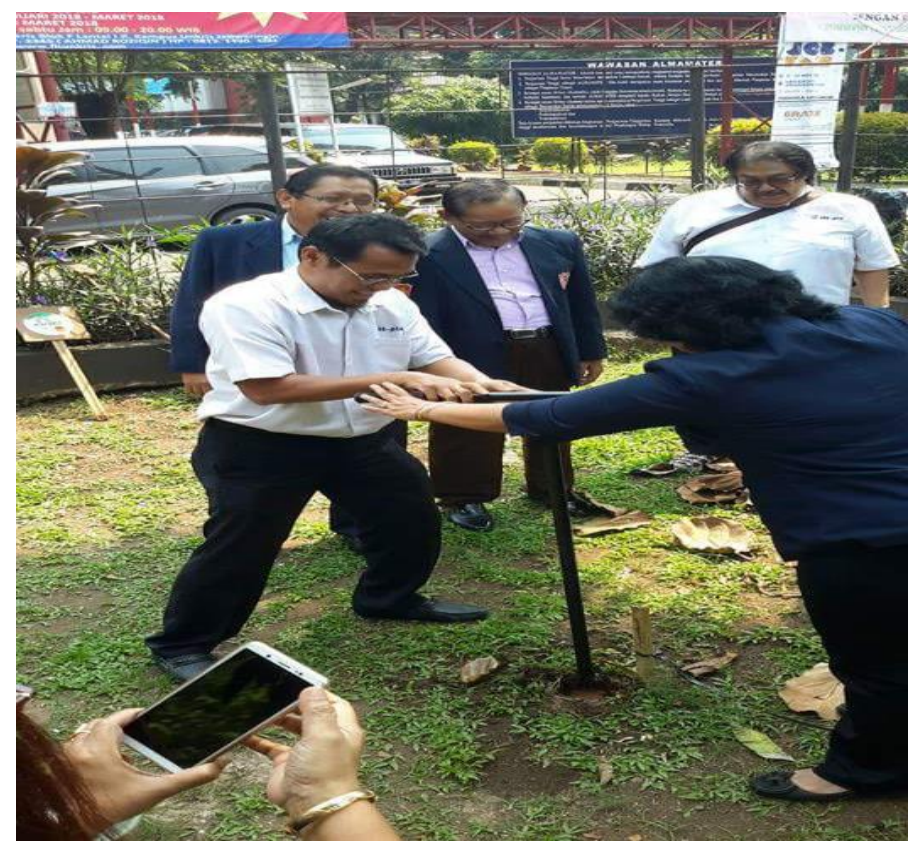

Gambar 7. Praktek Pembuatan LRB 


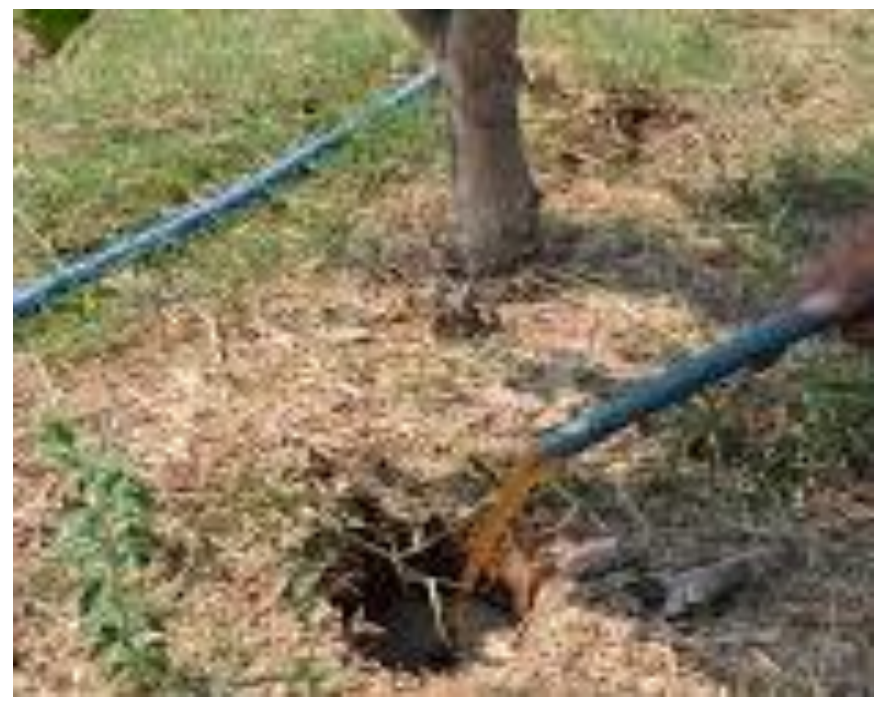

Gambar 8. Penyiraman Air Ke Dalam LRB Setelah Di Isi Sampah Organik

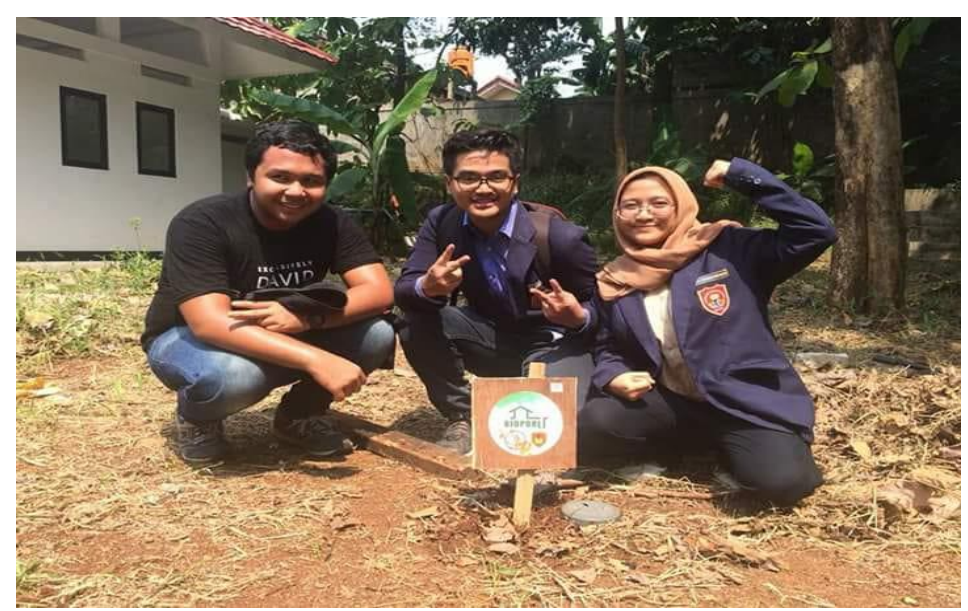

Gambar 9. Penandaan Letak LRB 


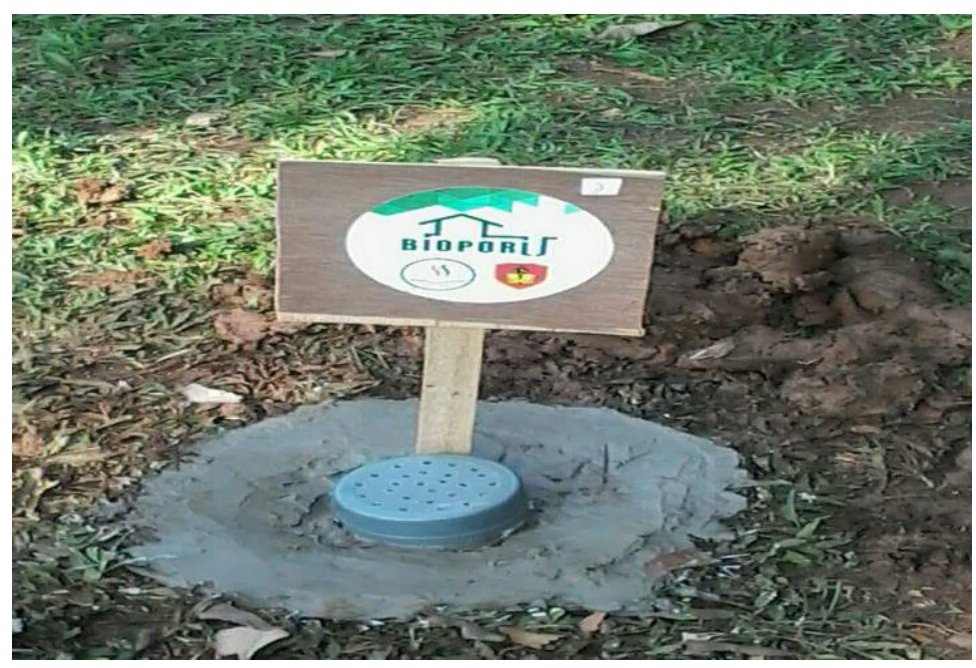

Gambar 10. Penutupan Mulut LRB

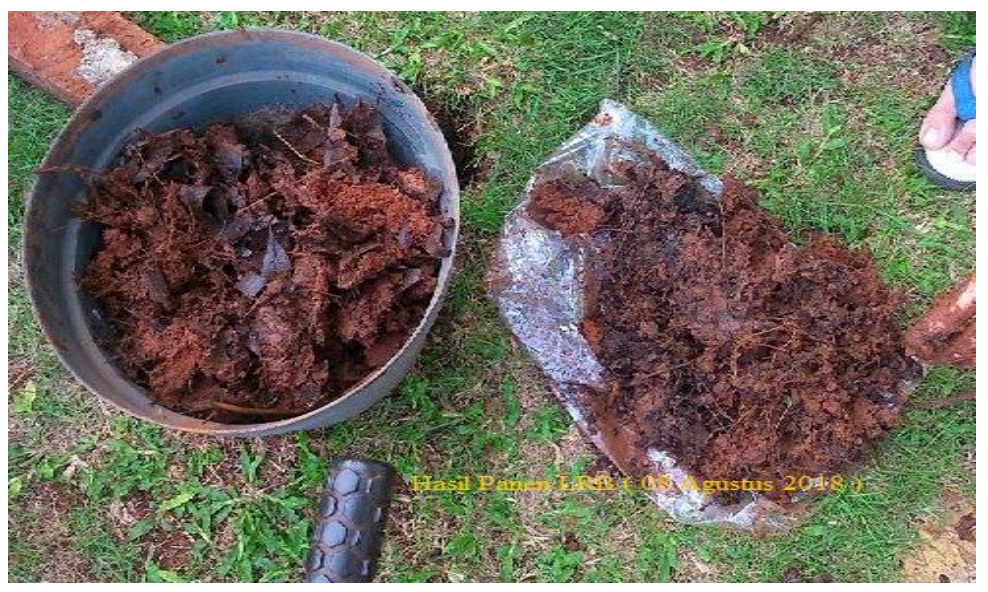

Gambar 11. Hasil Panen LRB ( Pupuk Organik )

\section{KESIMPULAN}

Sosialisasi tentang teknik pembuatan dan penyebaran Lubang Resapan Biopori ( LRB ) sebagai solusi untuk mengurangi banjir saat musim hujan dan menjaga kelestarian air tanah ( lingkungan ) saat musim kemarau di Fakultas Hukum UNKRIS secara positif membawa manfaat akan peningkatan pengetahuan apakah itu LRB, manfaat apa sajaa yang dapat di ambil dari adanya penyebaran LRB, apakah hubungan dari hukum lingkungan dengan LRB dan pemahaman tentang energi biomassa dari LRB yang dapat dipanen setelah 3 ( tiga ) - 4 ( empat ) bulan yang bernilai ekonomis. 


\section{SARAN}

STT-PLN perlu lebih menggalakkan dan meningkatkan program sosialisasi penyebaran lubang resapan biopori di lingkungan yang kurang drainese airnya dan apa sajakah dampak positif yang dapat diambil dari penyebaran LRB ini di wilayah yang khususnya terkena dampak banjir saat musim hujan, dan dampak kekeringan saat musim kemarau.

\section{UCAPAN TERIMA KASIH}

Penulis mengucapkan terima kasih kepada Sekolah Tinggi Teknik PLN yang telah membantu dalam kegiatan pengabdian pada masyarakat ini khususnya dalam hal pendanaan dan terima kasih juga kepada para peserta dari Fakultas Hukum Universitas Krisnadwipayana yang telah memberi kesempatan dan dukungan dalam pelaksanaan kegiatan pengabdian pada masyarakat.

\section{DAFTAR PUSTAKA}

1. Brata,Kamir R;Alistya,Anne,2008,Lubang Resapan Biopori, Penebar Swadaya, Jakarta.

2. Admin Padamu, Cara Membuat Lubang Resapan Biopori (LRB), https://www.padamu.net/cara-membuat-lubang-resapan-biopori-Irb , diakses tanggal 05 Maret 2018.

3. http://pusathukum.blogspot.com/2015/09/Materi-Kuliah-Hukum-Lingkungan.html

4. https://luk.staff.ugm.ac.id/atur/sda/PermenLH12-2009PemanfaatanAirHujan.pdf 